\title{
$\beta$-Galactosidase from Lactobacillus brevis PLA28: Purification, Characterization and Synthesis of Galacto-oligosaccharides
}

\author{
Bhalla TC*, Devi A, Angmo K, Thakur N and Kumari A
}

Professor, Department of Biotechnology, Himachal Pradesh University, Shimla, India, 171005

*Corresponding author: Tek Chand Bhalla, Professor, Department of Biotechnology, Himachal Pradesh University, Shimla, India, Tel: 91-177-2831948; E-mail: bhallatc@rediffmail.com

Rec date: Oct 13, 2015, Acc date: Dec 03, 2015, Pub date: Dec 14, 2015

Copyright: (c) 2013 Bhalla TC, et al. This is an open-access article distributed under the terms of the Creative Commons Attribution License, which permits unrestricted use, distribution, and reproduction in any medium, provided the original author and source are credited.

\begin{abstract}
Objective: Purification and characterization of $\beta$-galactosidase from Lactobacillus brevis PLA28 were carried out and transgalactosylation activity was also studied for the synthesis of galacto-oligosaccharides (GOS).

Methods: $\beta$-Galactosidase was purified by using ammonium sulphate precipitation method and hydrophobic interaction chromatography. Reaction conditions were optimized for the assay of this $\beta$-galactosidase. GOS synthesis was carried out under the optimized reaction conditions in batch mode and the product formed was detected by thin layered chromatography (TLC).

Results: $\beta$-Galactosidase was purified to 6.6 fold with a yield of $6 \%$ and specific activity of $4 \mathrm{U} / \mathrm{mg}$ protein. Molecular weight of the purified $\beta$-galactosidase was found to be 45 and $60 \mathrm{kDa}$ on SDS PAGE and $105 \mathrm{kDa}$ on native PAGE. The temperature and $\mathrm{pH}$ optima of purified enzyme were $30^{\circ} \mathrm{C}$ and $\mathrm{pH} 6.5$ respectively. The enzyme was found to be stable at $30^{\circ} \mathrm{C}$ for $6 \mathrm{~h}$. $\mathrm{V}_{\max }$ and $\mathrm{K}_{\mathrm{M}}$ of the purified $\beta$-galactosidase were calculated to be $6.6 \mathrm{U} / \mathrm{mg}$ protein and $8.33 \mathrm{mM}$ respectively. GOS synthesis was observed at $\mathrm{pH} 6.5,30^{\circ} \mathrm{C}$ in $6-8 \mathrm{~h}$ of incubation by purified enzyme.
\end{abstract}

Conclusion: Lactobacillus brevis PLA28 $\beta$-galactosidase has exhibited capability for transgalactosylation reaction with lactose conversion to synthesize GOS.

Keywords: $\beta$-Galactosidase; Lactobacillus brevis PLA28; Galactooligosaccharide

\section{Introduction}

Lactic acid bacteria (LAB) constitute a diverse group of lactococci, streptococci and lactobacilli. Enzymes obtained from these bacteria (LAB) are extensively studied for their use in food based industries. Lactic acid bacteria are found widely in nature and predominates the habitat that is rich in carbohydrates, protein breakdown products and vitamins. The utilization of the milk sugar lactose is a primary function of lactobacilli and other LAB [1]. Moreover, they are commonly associated with food fermentation and play a significant role in enhance nutritional quality and digestibility of food.

$\beta$-Galactosidase derived from lactic acid bacteria are studied extensively because of safety aspects and application in food industries. It catalyzes the hydrolysis of $\beta-1,4$-D-galactosidic linkages and has been used in dairy industry as an important biocatalyst [2]. The sources of this enzyme are plants, bacteria, animal organs, yeasts and moulds. Bacteria are preferred sources of $\beta$-galactosidase due to ease in their handling, stability and high enzyme activity [3]. This enzyme is used for the conversion of cheese whey, a waste from dairy industry into different valuable products [4]. It catalyzes hydrolysis of milk sugar lactose and structurally related galactosides and transgalactosylation reactions in which lactose serve as galactosyl acceptors, yielding a series of $\mathrm{di}$, tri-, and tetrasaccharides called galacto-oligosaccharides (GOS) [5]. Galacto-oligosaccharides along with the fructo-oligosaccharides are best studied prebiotics oligosaccharides that beneficially affect the host by selectively stimulating the growth and/or activity of probiotic bacteria in the colon.

The stability of GOS at high temperature and acidic conditions make them important in food and drink industries especially in confectionaries, acidic beverages and fermented milk products. Using $\beta$-galactosidases from isolates originated from fermented foods for the synthesis of prebiotic GOS is an interesting approach for the production of new carbohydrate-based functional food ingredients. The objective of present work was to purify $\beta$-galactosidase from $L$. brevis PLA28 and to study its transgalactosylation activity for the synthesis of GOS.

\section{Materials and methods}

\section{Chemicals}

All chemicals used in present study were purchased from Alfa Aesar, Johnson Matthey Company and Sigma (India). Man de, Rogosa and Sharpe (MRS) medium, Elliker HiVeg broth, and other media components were purchased from Himedia, Mumbai (India).

\section{Microorganism and culture conditions}

The LAB isolate $L$. brevis PLA28 was obtained from Research Lab II of Himachal Pradesh University (Shimla, India). It was isolated from chhang, a barley based traditional alcoholic beverage of Ladakh, India 
and identified by sequence analysis of the amplified chromosomal 16S rDNA. GenBank accession number for the $16 \mathrm{~S}$ rRNA gene sequence of L. brevis PLA28 is KJ722776. The bacterial culture was grown in Elliker HiVeg broth ( $\mathrm{pH} 6.8)$ at $30^{\circ} \mathrm{C}$ for $36 \mathrm{~h}$ in an incubator shaker. The cells from the culture were harvested by centrifugation at $10,000 \mathrm{~g}$ for 10 min at $4^{\circ} \mathrm{C}$ and washed twice with $50 \mathrm{mM}$ sodium phosphate buffer ( $\mathrm{pH}$ 7.0). After two washings with the same buffer, the cells were finally suspended in buffer and stored at $4^{\circ} \mathrm{C}$ and these cells were termed as resting cells.

\section{$\beta$-Galactosidase assay}

$\beta$-Galactosidase activity was estimated according to the method described by [6]. Specific activity of $\beta$-galactosidase was expressed as micromoles of oNP (o-nitrophenol) released per milligram of protein per min under the assay conditions. Protein concentration in the sample was determined by the method of [7], using bovine serum albumin as standard.

\section{Purification of $\boldsymbol{\beta}$ - galactosidase}

L. brevis PLA28 was cultured in $2 \mathrm{~L}$ Elliker broth at $30^{\circ} \mathrm{C}$ for $36 \mathrm{~h}$ and resting cells were prepared as described above. Cells of $L$. brevis PLA28 (450 mg dry cell weight) were suspended in sodium phosphate buffer (50 mM, pH 7) containing $1 \mathrm{mM}$ DTT (dithiothreitol), $1 \mathrm{mM}$ PMSF (phenylmethanesulfonyl fluoride), $1 \mathrm{mM}$ EDTA and disrupted by six successive disruption cycles with $0.5 \mathrm{~mm}$ glass beads using Bead Beater $^{\mathrm{TM}}$ (BioSpec Products, Inc.) on ice and the cell debris was removed by centrifugation at $10,000 \mathrm{~g}$ for $20 \mathrm{~min}$ at $4^{\circ} \mathrm{C}$. Supernatant was collected and termed as cell free extract (cell lysate) which was stored at $4^{\circ} \mathrm{C}$ for further purification steps.

\section{Ammonium sulphate precipitation}

The crude extract of $L$. brevis PLA28 was precipitated at $4^{\circ} \mathrm{C}$ using ammonium sulphate saturation (30-40\%). The resulting precipitates were suspended in $50 \mathrm{mM}$ sodium phosphate buffer ( $\mathrm{pH}$ 7.0) containing $2 \mathrm{mM} \mathrm{MgCl}, 1 \mathrm{mM}$ dithiothreitol (DTT), $1 \mathrm{mM}$ EDTA and $1 \mathrm{mM}$ PMSF and dialyzed overnight against the same buffer at $4^{\circ} \mathrm{C}$. The ammonium sulfate fractionate (ASF) having $\beta$-galactosidase activity was further used for purification.

\section{Hydrophobic interaction chromatography}

The dialyzed enzyme preparation was applied to phenyl sepharose column $(15 \mathrm{~cm} \times 1.5 \mathrm{~cm})$ and pre-equilibrated with $1 \mathrm{M} \mathrm{NaCl} / \mathrm{KCl}$ and sodium phosphate buffer $(\mathrm{pH} 7,50 \mathrm{mM})$. Protein was eluted with a linear gradient of $\mathrm{NaCl}(0.1 \mathrm{M}-1.0 \mathrm{M}$ in $50 \mathrm{mM}$ buffer, $\mathrm{pH} 7$ containing $1 \mathrm{mM}$ DTT and $1 \mathrm{mM}$ EDTA) at a flow rate of $0.5 \mathrm{ml} / \mathrm{min}$ and fractions of $2 \mathrm{ml}$ were collected.

\section{Determination of molecular weight of $\beta$-galactosidase of $L$. brevis PLA28}

Molecular weight of the purified $\beta$-galactosidase was determined by SDS (sodium dodecyl gel electrophoresis) and Native-PAGE.

\section{Characterization of purified enzyme}

The activity of purified $\beta$-galactosidase assayed in various buffer systems, i.e., citrate buffer ( $\mathrm{pH} 3-6$ ), borate buffer ( $\mathrm{pH} \mathrm{5-7),} \mathrm{potassium}$ phosphate buffer ( $\mathrm{pH}$ 6-8), tris-HCl buffer ( $\mathrm{pH}$ 6-9), sodium carbonate buffer ( $\mathrm{pH} 9-10)$, sodium phosphate buffer $(\mathrm{pH}$ 6.5-7.5) and borax buffer ( $\mathrm{pH} 9-10)$ of $0.1 \mathrm{M}$. The effect of buffer molarity (0.025-0.2 M), substrate concentration $(0.002-0.06 \mathrm{M})$, temperature $\left(25-50^{\circ} \mathrm{C}\right)$ and incubation time $(5-30 \mathrm{~min})$ on the activity of the purified $\beta$ galactosidase were explored. Thermal stability of the $\beta$-galactosidase was also studied at temperatures $30^{\circ} \mathrm{C}, 35^{\circ} \mathrm{C}, 45^{\circ} \mathrm{C}$, and $55^{\circ} \mathrm{C}$ for $6 \mathrm{~h}$.

\section{Synthesis of galacto-oligosaccharides using $\boldsymbol{\beta}$-galactosidase of $L$. brevis PLA28}

Synthesis of galacto-oligosaccharides (GOS) was carried out in discontinuous mode at $30^{\circ} \mathrm{C}$ using purified $\beta$-galactosidase from $L$. brevis PLA28 according to the method described by Iqbal et al. [8] .The synthesized product formed was analyzed by thin layer chromatography according to the procedure of Iqbal et al. [8].

\section{Results}

\section{Purification}

The purification of $\beta$-galactosidase from $L$. brevis PLA28 was achieved in two steps summarized in Table 1. This enzyme was purified by applying ammonium sulphate precipitation method and hydrophobic interaction chromatography. It was purified to 6.6 fold with a yield of $6 \%$ (Table 1). Specific activity of the purified enzyme was found to be $4.0 \mathrm{U} / \mathrm{mg}$ protein. The purified $\beta$-galactosidase of $L$. brevis PLA28 consists of two distinct protein bands, which confirmed the dimeric nature of this enzyme. SDS-PAGE analysis of the $\beta$ galactosidase showed protein bands of 45 and $60 \mathrm{kDa}$ while in native PAGE a single band of $105 \mathrm{kDa}$ was observed (Figures 1 and 2).

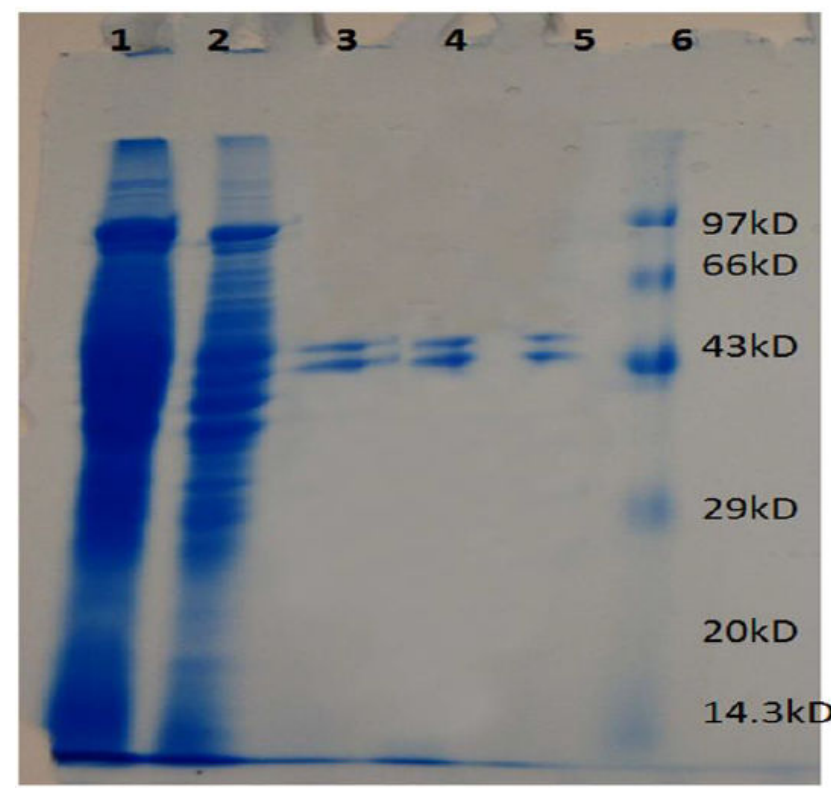

Figure 1: SDS-PAGE of purified $\beta$-galactosidase from $L$. brevis LA-63. lane 1: crude, lane 2: dialyzed sample, lane 3, 4, 5: purified samples, lane 6: marker. 
Citation: Bhalla TC (2015) $\beta$-Galactosidase from Lactobacillus brevis PLA28: Purification, Characterization and Synthesis of Galactooligosaccharides. J Food Ind Microbiol 1: 104.

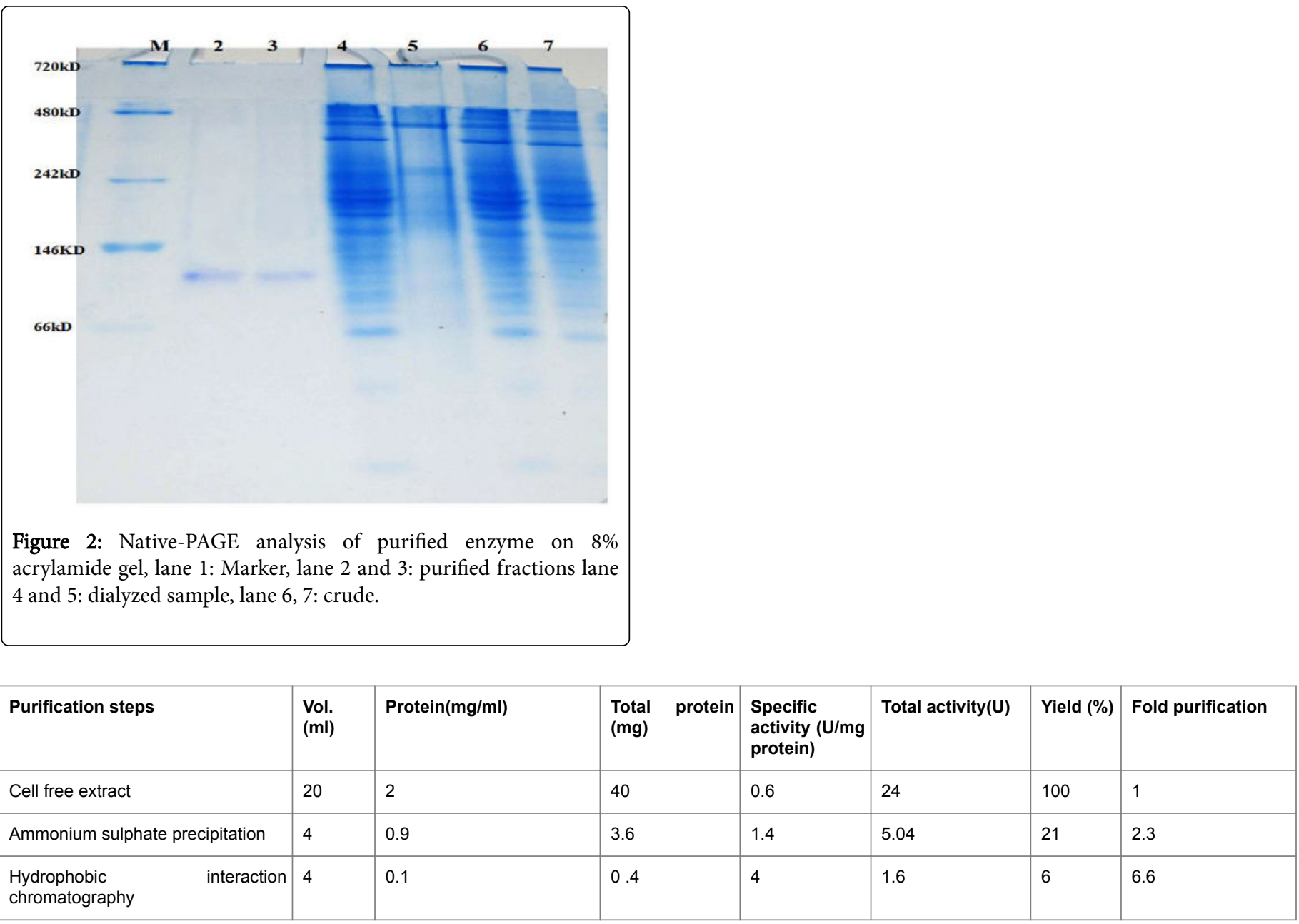

Table 1: Purification summary of $\beta$-galactosidase of L. brevis PLA-28.

\section{Characterization of purified enzyme}

\section{Buffer $\mathrm{pH}$ and molarity}

\section{Temperature}

Optimum temperatures for the hydrolysis of ONPG was found to be $30^{\circ} \mathrm{C}$ with specific activity of $4.3 \mathrm{U} / \mathrm{mg}$ protein, although this enzyme was quite active at $25-50^{\circ} \mathrm{C}$ (Figure 3 ).

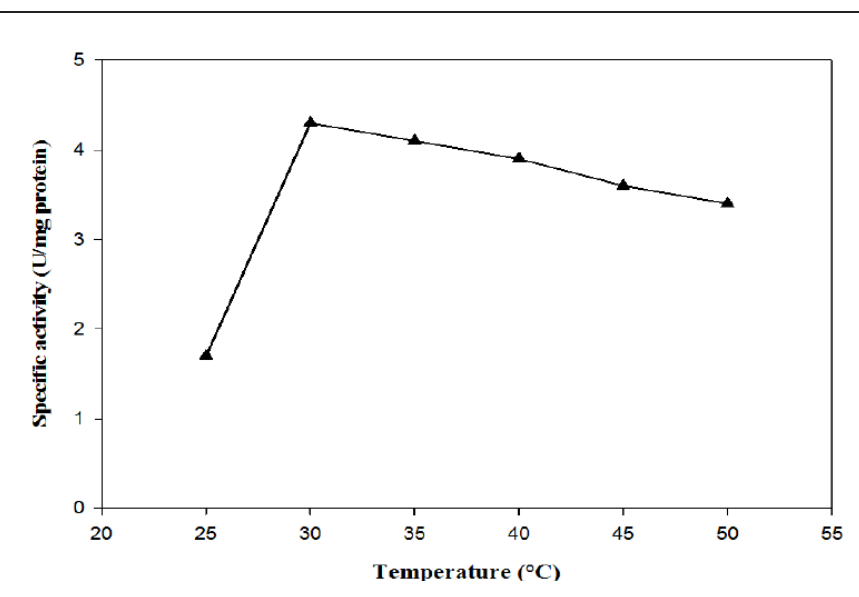

Figure 3: Effect of temperature on $\beta$-galactosidase of $L$. brevis PLA28. 


\section{Incubation time}

To optimize the reaction time for assay of $\beta$-galactosidase, the reaction mixture was incubated at $30^{\circ} \mathrm{C}$ for $5-30 \mathrm{~min}$. The highest specific enzyme activity ( $4.3 \mathrm{U} / \mathrm{mg}$ protein) was observed at $10 \mathrm{~min}$ of incubation.

\section{Substrate concentration}

The effect of substrate concentration on $\beta$-galactosidase activity revealed that the enzyme exhibited highest activity ( $4.6 \mathrm{U} / \mathrm{mg}$ protein) at $10 \mathrm{mM}$ substrate concentration in the reaction. The activity of $\beta$ galactosidase remained constant when substrate concentration was increased above $10 \mathrm{mM}$ (Figure 4).

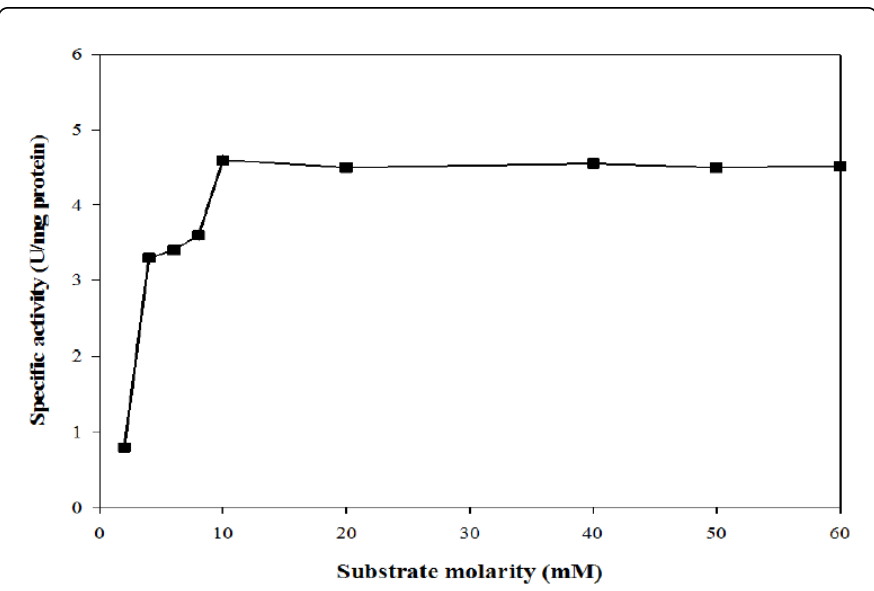

Figure 4: Effect of substrate concentration on $\beta$-galactosidase of $L$. brevis PLA28.

\section{Thermal stability}

Thermostability profile of $\beta$-galactosidase revealed no loss in catalytic activity of enzyme at $30^{\circ} \mathrm{C}$ and $35^{\circ} \mathrm{C}$ till $6 \mathrm{~h}$ whereas at $45^{\circ} \mathrm{C}$ the half life of enzyme was found to be $1.31 \mathrm{~h}$ while half life of the enzyme was recorded to be $30 \mathrm{~min}$ at $55^{\circ} \mathrm{C}$.

\section{Kinetic constants}

The analysis of Lineweaver-Burk plot showed that $\beta$-galactosidase had $\mathrm{K}_{\mathrm{M}}$ of $8.33 \mathrm{mM}$ and $\mathrm{V}_{\max }$ of $6.6 \mathrm{U} / \mathrm{mg}$ protein.

\section{Synthesis of galacto-oligosaccharides using $\beta$-galactosidase of $L$. brevis PLA28}

In order to assess the potential of $\beta$-galactosidase from $L$. brevis PLA28 for the synthesis of galaco-oligosaccharides (GOS), a discontinuous lactose conversion process was studied at $30^{\circ} \mathrm{C}$, using an initial lactose concentration $(50-200 \mathrm{mg} / \mathrm{ml})$, enzyme $(0.5-5.0 \mathrm{U} / \mathrm{ml})$, and $\mathrm{pH} 6.5$ at $30^{\circ} \mathrm{C}$. Samples collected at regular intervals of time and analyzed by thin layer chromatography (TLC). The TLC chromatograms were developed for standards and the samples. The galacto-oligosaccharides (GOS) synthesis was recorded at $4-8 \mathrm{~h}$ of incubation. The TLC chromatogram demonstrated the transgalactosylation capability of $\beta$-galactosidase, as the group of sugars appeared at the position corresponding to oligosaccharides. The galacto-oligosaccharides (GOS) synthesis was observed with substrate of $200 \mathrm{mg} / \mathrm{ml}$ and enzyme of $5 \mathrm{U} / \mathrm{ml}$ at $\mathrm{pH} 6.5$ at $30^{\circ} \mathrm{C}$ in 6 to $8^{\text {th }} \mathrm{h}$ of incubation.

\section{Discussion}

The purpose of the present study was to purify, characterize and explore the potential of $\beta$-galactosidase from $L$. brevis PLA28 for the synthesis of GOS. It is interesting to study and characterize enzymes from microorganisms which are isolated from traditional fermented food products as use of such enzymes does not involve risk and are safe from health view point. Thus, Lactobacillus $\beta$-galactosidase originated from food products is safe for utilization in food industry as LAB are considered as GRAS (Generally regarded as safe). Vasiljevic and Jelen [9], reported that the enzyme derived from GRAS microorganisms e.g. $\mathrm{LAB}$ can be used without extensive purification. On the other hand, Lactobacilli are gaining a significant interest for its probiotic properties such as an improvement in lactose digestion and microbial balance in gastrointestinal tract which directly contribute benefit to host health $[10,11]$.

$\beta$-Galactosidase from $L$. brevis PLA 28 is a heterodimer consisting of two subunits of approximately 45 and $30 \mathrm{kDa}$. In accordance with our result, majority of Lactobacilli $\beta$-galactosidases exist as hetrodimer (72 $\mathrm{kDa}$ and $35 \mathrm{kDa}$ ) that have been reported in L. brevis KB290 [12], Lactobacillus acidophilus R22 [6], Lactobacillus reuteri [13]. However, $\beta$-galactosidase from L. salivarius was reported to be a monomer of 30 $\mathrm{kDa}$ Bae while this enzyme exists as homodimer of $220 \mathrm{kDa}$ [14] homotetramer of $257 \mathrm{kDa}$ [15], in L. delbrueckii subsp. bulgaricus and L. helveticus respectively.

Hung and Lee [16], reported that the optimum $\mathrm{pH}$ for $\beta$ galactosidase enzyme from microbial sources range around $\mathrm{pH}$ 3.0-7.2. In this study, optimum $\mathrm{pH}$ was determined to be $6.5 \mathrm{pH}$ while activity of this enzyme decreased gradually at $\mathrm{pH}$ values higher or lower than the optimum $\mathrm{pH}$ value. These results agree with the observation reported by Iqbal et al. [8], that the $\mathrm{pH}$ optimum of $\beta$ - galactosidase from Lactobacillus sakei Lb790 was pH 6.5.

Optimum temperature for the hydrolysis of oNPG was found to be $30^{\circ} \mathrm{C}$, although this enzyme was active at $25-50^{\circ} \mathrm{C}$. The loss of activity of the enzyme at higher temperatures could be attributed to its unfolding and subsequent loss of active site [17]. Similar findings were reported by $\mathrm{Ku}$ and Hang [18-20]. The substrate optimum for L. brevis PLA $28 \beta$-galactosidase was $10 \mathrm{mM}$. It was observed that the $\beta$ galactosidase activity remained constant when substrate concentration was increased above $10 \mathrm{mM}$, hence suggesting that this enzyme is not prone to inhibition by higher concentration of substrate [21], reported that $\beta$-galactosidase of Streptococcus thermophilus exhibited maximum activity of $24 \mathrm{mM}$ (oNPG) as substrate. Kinetic constants $\mathrm{KM}$ and Vmax of purified $\beta$-galactosidases for oNPG was calculated to be $8.33 \mathrm{mM}$ and $6.6 \mathrm{U} / \mathrm{mg}$ protein respectively. $\mathrm{KM}$ and $\mathrm{V}_{\max }$ values have been reported in Bacillus sp. as (6.34 mM and $9351 \mathrm{IU} \mathrm{ml}-1)$, Penicillium chrysogenum (1.81 mM and $\left.40 \mathrm{nkat} \mathrm{mg}^{-1}\right)$, Thalassospira sp. $(1.2 \mathrm{mM}$ and $1,645.66 \mathrm{U} / \mathrm{ml})$ and Lactobacillus pentosus $(1.67 \mathrm{mM}$

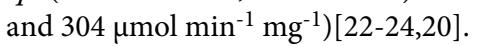

Lactose utilization is an important biochemical characteristic of lactobacilli and other LAB (lactic acid bacteria) used in the fermentation of milk. $\beta$-Galactosidases play a crucial role in the metabolism of lactose in lactobacilli however, little attention has been paid to study its transgalactosylation activity for synthesis of GOS. GOS find their important application in the formulations of functional food because of their proven health benefits [3,25-29]. $\beta$-galactosidase 
of $L$. brevis PLA28 catalyzed transgalactosylation reaction as reported earlier in case of $\beta$-galactosidase from Lactobacillus pentosus, Lactobacillus plantarum WCFS1, L. sakei Lb790[1,8], respectively.

\section{Conclusions}

The transgalactosylation activity of purified $\beta$-galactosidase from $L$. brevis PLA28 has potential application in GOS synthesis. Since $L$. brevis PLA28 has been isolated from fermented food, therefore its $\beta$ galactosidase has ample scope for synthesis of products in food and pharmaceutical industry.

\section{Acknowledgement}

Authors are grateful to the Department of Biotechnology (DBT), Ministry of Science and Technology, Government of India and University Grants Commission, New Delhi for financial support. We are also thankful to Dr. R. B. Srivastava, Director, DIHAR, DRDO, Leh-Ladakh, and Dr. Tsering Stobdan, Horticulture Division, DIHAR, DRDO, Leh-Ladakh for giving permission and providing facilities to do part of research work in their Laboratory.

\section{References}

1. Iqbal S, Nguyen TH, Nguyen TT, Maischberger T, Haltrich D, et al.(2010) $\beta$-galactosidase from Lactobacillus plantarum WCFS1: biochemical characterization and formation of prebiotic prebiotic galactooligosaccharides. Carbohydrate research 345: 1408-1416.

2. Nguyen TT, Nguyen HA, Arreola SL, Mlynek G, Djinovic-Carugo D, et al. (2012) Homodimeric $\beta$-galactosidase from Lactobacillus delbrueckii subsp. bulgaricus DSM 20081:expression in Lactobacillus plantarum and biochemical characterization. J Agric Food Chem 60: 1713-1721.

3. Park AR, Oh DK (2010) Galacto-oligosaccharide production using microbial beta-galactosidase: current state and perspectives. Appl Microbiol Biotechnol 85: 1279-1286.

4. Sharma S, Singh P (2014) Isolation and characterization of $\beta$ galactosidase enzyme producing microbe and optimization of its enzyme activity under different culture condition. Int J Curr Microbiol App Sci 3: 148-155.

5. Torres DP, Goncalves M, Teixeira JA, Rodrigues LR (2010) Galactooligosaccharides: production, properties, applications, and significance as prebiotics. Compr Rev Food Sci F 9: 438-454.

6. Nguyen TH, Splechtna B, Krasteva S, Kneifel W, Kulbe KD, et al. (2007) Characterization and molecular cloning of a heterodimeric bgalactosidase from the probiotic strain Lactobacillus acidophilus R22. FEMS Microbiol Lett 269: 136-144.

7. Bradford MM (1976) A rapid and sensitive method for the quantitation of 475 microgram quantities of protein utilizing the principle of protein dye binding. Anal Biochem 72: 284-254.

8. Iqbal S, Nguyen TH, Nguyen HA, Nguyen TT, Maischberger T, et al (2011) Characterization of a heterodimeric GH2 $\beta$-galactosidase from Lactobacillus sakei Lb790 and formation of prebiotic galactooligosaccharides. J Agric Food Chem 59: 3803-3811.

9. Vasiljevic T, Jelen P (2002) Lactose hydrolysis in milk as affected by neutralizers used for the preparation of crude $\beta$-galactosidase extracts from Lactobacillus delbrueckii subsp. bulgaricus 11842. Innov Food Sci Emerg Technol 3: 175-184.

10. Vinderola CG, Reinheimer JA (2003) Lactic acid starter and probiotic bacteria: a comparative in vitro study of probiotic characteristics and biological barrier resistance. Food Res Intern 36: 895-904.
11. Ljungh A, Wadstrom T (2006) Lactic acid bacteria as probiotics. Curr. Issues Intestinal Microbiol7: 73-90.

12. Honda H, Yajima N, Saito T (2012) Characterization of lactose utilization and $\beta$-galactosidase in Lactobacillus brevis KB290, the heterofermentative lactic acid bacterium. Curr Microbiol 65: 679-685.

13. Splechtna B, Nguyen TH, Kulbe KD, Lorenz W, Haltrich D (2006) Production of prebiotic galactosaccharides from lactose using $\beta$ galactosidase from Lactobacillus reuteri. J Agric Food Chem 54: 4999-5006.

14. Adams RM, Yoast S, Mainzer SE, Moon K, Palombella AL, et al. (1994) Characterization of two cold-sensitive mutants of the $\beta$-galactosidase from Lactobacillus delbruckii subsp. bulgaricus. J Biol Chem 269: 5666-5672.

15.

16.

17. HaiderT, Husain Q (2007) Preparation of lactose free milk by using salt fractionated almond (Amygadaluscommunis) $\beta$-galactosidase. J Sci Food Agric 87: 1278-1283.

18. Ku MA, Hang YD (1992) Production of yeast lactase from sauerkraut brine. Biotechnol Letts14: 925-928.

19. Artolozaga MJ, Jones R, Schneider AL, Furlan SA, Carvallo-Jones MF, et al. (1998) One step partial purification of $\beta$-D-galactosidase from Kluyveromyces marxianus CDB002 using streamline-DEAE. Bioseparation 7: 137-143.

20. Ghosh M, Pulicherla KK, Rekha VPB, Kumar Raja P, Sambasiva Rao KRS (2012) Cold active $\beta$-galactosidase from Thalassospira sp. 3SC-21 to use in milk lactose hydrolysis: a novel source from deep waters of Bay-ofBengal. World J Microbiol Biotechnol 28: 2859-2869.

21. Princely S, Basha SN, Kirubakaran J, Dhanaraju MD (2013) Biochemical characterization, partial purification, and production of an intracellular beta-galactosidase from Streptococcus thermophilus grown in whey. European Journal of Experimental Biology 3: 242-251.

22. Chakraborti S, Sani RK, Banerjee UC, RC Sobti (2000) Purification and characterization of a novel $\beta$-galactosidase from Bacillus sp MTCC 3088. Journal of Industrial Microbiology and Biotechnology 24: 58-63.

23. Nagy Z, Kiss T, Szentirmai A, Biro S (2001) $\beta$-Galactosidase of Penicillium chrysogenum: Production, purification, and characterization of the enzyme. Protein Expression and Purification 21: 24-29.

24. Maischberger T, Leitner E, Nitisinprasert S, Juajun O, Yamabhai M, et al. (2010) Galactosidase from Lactobacillus pentosus: Purification, characterization and formation of galacto-oligosaccharides. Biotechnol J 5: 838-847.

25. Macfarlane GT, Steed H, Macfarlane S (2008) Bacterial metabolism and health related effects of galacto-oligosaccharides and other prebiotics. J Appl Microbiol 104: 305-344.

26. Gosling A, Stevens GW, Barber AR, Kentish SE, Gras SL (2010) Recent advances refining galactooligosaccharide production from lactose. Food Chem 121: 307-318.

27. Bae HC, Choi JW, Nam MS (2007) Purification and characterisation of $\beta$ galactosidase from Lactobacillus salivarius subsp. salivarius Nam27. Korean J Food Sci Ani resour 27: 110-116.

28. Kim YS, Park CS, Oh DK (2006) Lactulose production from lactose and fructose by a thermostable $\beta$-galactosidase from Sulfolobus solfataricus. Enzyme Microb Technol 39: 903-909.

29. Nguyen TH, Splechtna B, Steinbock M, Kneifel W, Lettner HP, et al. (2006) Purification and characterization of two novel b-galactosidases from Lactobacillus reuteri. J Agric Food Chem 54: 4989-4998. 